\title{
Anticariogenic effect of fluoride-releasing elastomers in orthodontic patients
}

\author{
Efeito anti-cariogênico de elastômeros \\ liberadores de fluoreto em pacientes \\ ortodônticos
}

\author{
Karina Katsue Miura ${ }^{(a)}$ \\ Izabel Yoko Ito(b) \\ Carla Enoki(c) \\ Ana Maria Elias(d) \\ Mírian Aiko Nakane Matsumoto ${ }^{(e)}$
}

\begin{abstract}
(a) Orthodontics Specialist; (c) PhD, Professor of Orthodontics, Department of Pediatric Dentistry; (e) PhD, Professor of Orthodontics, Department of Pediatric Dentistry - School of Dentistry of Ribeirão Preto, University of São Paulo.
\end{abstract}

(b) PhD, Professor of Microbiology, Department of Clinical Analysis, Toxicology and Bromatology, School of Pharmaceutical Sciences of Ribeirão Preto, University of São Paulo.

(d) MS, Professor of Statistics, College of Science and Letters of Araraquara, State University of São Paulo.

\begin{abstract}
This in vivo experimental study evaluated the efficacy of fluoride-releasing elastomers in the control of Streptococcus mutans levels in the oral cavity. Forty orthodontic patients were recruited and divided into two groups of 20. Fluoride-releasing elastomeric ligature ties (Fluor-I-Ties, Ortho Arch Co. Inc., USA) were used in the experimental group, and conventional elastomeric ligature ties (D. Morelli, Brazil), in the control group. Two initial samples of saliva were collected at a 14-day interval to determine the number of colony forming units (CFU) of Streptococcus mutans. Immediately after collecting the second sample, fluoride-releasing elastomeric ligature ties were placed in the patients of the experimental group, and conventional ligature ties, in the patients of the control group. Seven, 14 and 28 days after placement of the elastomeric ligature ties, saliva and plaque surrounding the orthodontic appliance were collected for microbiologic analysis. There were no significant differences in the number of Streptococcus mutans CFUs in saliva or plaque in the area surrounding the fluoride-releasing or conventional elastomeric ligature ties. Thus, fluoride-releasing elastomeric ligature ties should not be indicated to reduce the incidence of enamel decalcification in orthodontic patients. Since there was no significant reduction in $S$. mutans in saliva or plaque, other means of prevention against enamel decalcification should be indicated for these patients.
\end{abstract}

Descriptors: Streptococcus mutans; Elastomers; Fluorides, topical; Orthodontic appliances.

Resumo: Esta pesquisa in vivo teve como objetivo avaliar a eficácia dos elastômeros liberadores de fluoreto estanoso no controle dos níveis de Streptococcus do grupo mutans na cavidade oral. Utilizou-se uma amostra de 40 pacientes ortodônticos, dividida em dois grupos de vinte indivíduos cada. No grupo experimental, foi utilizada ligadura elástica com liberação de fluoretos (Fluor-I-Ties, Ortho Arch Co. Inc., EUA) e, no grupo controle, foi utilizada ligadura elástica convencional (D. Morelli, Brasil). Para determinação do número de unidades formadoras de colônia (UFC) de Streptococcus do grupo mutans, foram realizadas duas coletas iniciais de saliva com intervalo de catorze dias. Logo após a segunda coleta de saliva, foram colocados os elastômeros liberadores de fluoretos nos pacientes do grupo experimental e, nos pacientes do grupo controle, foram inseridos os elastômeros convencionais. Nos $7^{\circ}, 14^{\circ}$ e $28^{\circ}$ dias, saliva e biofilme ao redor do acessório ortodôntico foram coletados para análise microbiológica. Constatou-se que não houve diferenças estatisticamente significantes no número de UFC de Streptococcus do grupo mutans encontradas na saliva e no biofilme ao redor dos elastômeros com ou sem fluoretos. Dessa forma, os elastômeros liberadores de fluoreto não podem ser utilizados para reduzir a incidência de descalcificação do esmalte em pacientes ortodônticos. Como não houve redução significativa na quantidade de $S$. mutans na saliva e no biofilme, torna-se necessário indicar outros meios de prevenção da descalcificação do esmalte para esses pacientes. Descritores: Streptococcus mutans; Elastômeros; Fluoretos tópicos; Aparelhos ortodônticos.
Received for publication on Feb 16, 2006 Sent for alterations on Sep 22, 2006 Accepted for publication on Oct 17, 2006 


\section{Introduction}

The purpose of orthodontic treatment with fixed appliances is to improve function and esthetics. However, appliances predispose to the accumulation of bacterial plaque and increase the risk of developing periodontal disease $\mathrm{e}^{5}$ and carious lesions that may rapidly progress because of the intense demineralization around the brackets and under orthodontic bands.

Studies have shown that most patients that undergo orthodontic treatment have some type of enamel lesion after the removal of the appliance. ${ }^{10,16}$ During orthodontic treatment, there is a significant increase in the number of Streptococcus mutans CFUs $^{1,8,19,20}$ and lactobacilli, ${ }^{1,4}$ which is associated with the development of white spots and later development of carious lesions. ${ }^{11}$

Therefore, the prevention of enamel decalcification during orthodontic therapy is one of the greatest challenges for the orthodontist. White spots are an esthetic problem and may require restorations in more severe cases, thus undermining one of the main purposes of treatment.

During orthodontic treatment, some preventive measures may be adopted to protect tooth structure. ${ }^{9}$ Oral hygiene instruction and supervision, mechanical removal of plaque and daily mouth rinses with fluoride solutions are some of the methods used by the orthodontist that depend on the cooperation of the patient. Ideal prevention should not depend on patient cooperation, and application of sealing material, fluoride collagen materials and cements, and fluoride varnishes around the bracket may achieve this objective. ${ }^{22}$

Successful attempts to reduce susceptibility to enamel decalcification have been made with the use of fluoride agents ${ }^{15,22,26}$ that enhance remineralization in the presence of critical $\mathrm{pH}$, inhibit plaque glycolysis, and promote the formation of high-quality fluorapatite. ${ }^{15}$ Fluoride has bactericide and bacteriostatic ${ }^{7}$ properties that act on microorganisms in the oral cavity, such as Streptococcus mutans. ${ }^{13}$

Fluoride-releasing elastomers can continuously release these agents in areas close to the areas more susceptible to demineralization. ${ }^{2,3,14}$ In vitro studies have demonstrated that the initial amount of fluo- ride released by fluoride-releasing elastomeric ligature ties is high, but levels decrease logarithmically after one week..$^{6,12,21,25}$ The use of these materials also temporarily reduces the levels of $S$. mutans in saliva $^{23}$ and increases enamel resistance at a $20-\mathrm{mi}^{-}$ crometer depth after one month in the oral cavity. ${ }^{24}$

Other in vitro studies also found greater formation of calcium fluoride in enamel after the use of these elastomers, and that the greater the direct contact between the releasing source and the enamel, the greater the increase in the amount of fluoride. ${ }^{17,18}$

The purpose of this study was to evaluate the efficacy of fluoride-releasing elastomers in the control of Streptococcus mutans levels in the oral cavity by counting the number of CFUs in saliva and plaque surrounding the orthodontic appliance.

\section{Material and Methods}

The present study was approved by the Ethics Committee, School of Dentistry of Ribeirão Preto, University of São Paulo (process \# 2002.1.440.586). Forty 12 - to 20 -year-old boys and girls were selected among patients of the Orthodontics Clinic. Patients using antibiotics or with signs of systemic disease were excluded. Patients were randomly distributed into two groups. Fluoride-releasing elastomeric ligature ties (Fluor-I-Ties, Ortho Arch Co. Inc., USA) were used in the experimental group, and conventional elastomeric ligature ties (D. Morelli, Sorocaba, SP, Brazil), in the control group. Dental hygiene instructions consisted in guiding patients through brushing their teeth with sodium fluoride toothpaste (Colgate Paste, Colgate-Palmolive Co., Osasco, SP, Brazil). Fluoride mouth rinses were not prescribed.

Two samples of saliva were collected at a 14-day interval to determine the number of Streptococcus mutans CFUs; $2.0 \mathrm{ml}$ of non-stimulated saliva were collected from both groups. Samples were collected in properly identified $15 \times 100 \mathrm{~mm}$ sterilized tubes containing 4 to 5 glass beads, and processed at the Microbiology Laboratory, School of Pharmaceutical Science of Ribeirão Preto, University of São Paulo.

Immediately after the second saliva collection, patients in the experimental group received fluoridereleasing elastomeric ligature ties (Fluor-I-Ties, Ortho Arch Co. Inc., USA), while the patients in the 
control group received conventional elastomeric ligature ties (D. Morelli, Sorocaba, SP, Brazil).

On days 7,14 and 28 after the placement of the elastomeric ligature ties, saliva and plaque samples were collected from both groups. A sterilized curette was used to collect plaque samples from the area surrounding the ligature ties of the right maxillary lateral incisor, left maxillary second premolar, left mandibular canine and right mandibular second premolar. Plaque was transferred to $15 \times 100 \mathrm{~mm}$, properly identified, sterilized test tubes containing 4 to 5 glass beads and $1.0 \mathrm{ml}$ of phosphate buffered saline (PBS).

Plaque and saliva samples were vortexed for one and two minutes, respectively, for dispersion, and submitted to tenfold serial dilution. After that, $50 \mu \mathrm{l}$ of each dilution was plated equidistantly on tryptone soya-yeast agar with $20 \%$ sucrose and $0.2 \mathrm{U} / \mathrm{ml}$ bacitracin $\left(\mathrm{SB}_{20}\right.$ agar; Sigma, St. Louis, MO, USA) and incubated in a candle jar at $37^{\circ} \mathrm{C}$ for 2 to 3 days.

\section{Statistical analysis}

Only 32 of the 40 patients remained until the end of the study. Of these, 17 belonged to the control group and 15 , to the experimental group.

Exploratory analysis of data showed that, of all patients, only one in the control group had low risk of caries during the treatment $\left(<10^{4}\right.$ CFUs in saliva). Data about this patient was excluded from analysis, and the number of patients in the control group was then 16.

For statistical analysis, the original data, measured as number of CFUs, were transformed to $\log _{10}(\mathrm{CFU})$, which will henceforth be referred to only as $\log (\mathrm{CFU})$. In the analysis of the effect of type of elastomeric material on the number of CFU in plaque at each time point, $\log (\mathrm{CFU})$ in plaque was calculated according to the mean number of CFUs in the four teeth of each patient.

The Hotelling's T-squared test was used for multivariate analysis of the comparison of repeated measures. After the confirmation that the vectors of $\log (\mathrm{CFU})$ means in saliva in the two groups were equal, that is, that the saliva conditions were similar and unchanged along time, Hotelling's T-squared test for multivariate analysis of the comparison of repeated measures was used to compare $\log (\mathrm{CFU})$ means in plaque of the two groups at 7, 14 and 28 days after placement of the elastomeric ligature ties.

\section{Results}

Table 1 shows the results of $\log (\mathrm{CFU})$ in saliva, which reveal that patients had moderate to high risk of caries both in the experimental and the control groups at each time point in the study (Graph 1). The results of the Hotelling's T-squared test showed no evidence of statistical difference between the two groups at each time point in the study $(\mathrm{F}=1.039$; $\mathrm{df}=4$ and $26 ; \mathrm{p}=0.406$ ), that is, there was no evidence of differences between the two groups or of significant changes in number of CFUs in saliva during this study.

Table 1 - Means, standard deviations, minimum and maximum values of $S$. mutans $\log (C F U)$ in saliva according to group and treatment time point.

\begin{tabular}{c|l|c|c|c|c}
\hline Time & \multicolumn{1}{|c|}{ Group } & Mean & SD & Minimum & Maximum \\
\hline \multirow{3}{*}{ Before } & Control & 6.217 & 0.818 & 7.354 & 4.143 \\
\cline { 2 - 6 } & Experimental & 6.069 & 0.843 & 7.350 & 4.602 \\
\hline \multirow{3}{*}{ Initial } & Control & 6.006 & 0.644 & 6.973 & 4.748 \\
\cline { 2 - 6 } & Experimental & 5.982 & 0.733 & 7.283 & 5.083 \\
\hline \multirow{2}{*}{7 days } & Control & 5.962 & 0.782 & 6.924 & 4.072 \\
\cline { 2 - 6 } & Experimental & 5.943 & 0.885 & 7.292 & 4.544 \\
\hline \multirow{3}{*}{14 days } & Control & 6.154 & 0.752 & 6.944 & 4.124 \\
\cline { 2 - 6 } & Experimental & 5.945 & 0.781 & 7.220 & 4.393 \\
\hline \multirow{2}{*}{28 days } & Control & 6.008 & 0.680 & 6.886 & 4.000 \\
\cline { 2 - 6 } & Experimental & 6.167 & 0.774 & 7.121 & 4.623 \\
\hline
\end{tabular}

Hotelling's T-squared test: $F=1.039 ; \mathrm{df}=4$ and $26 ; \mathrm{p}=0.406$.

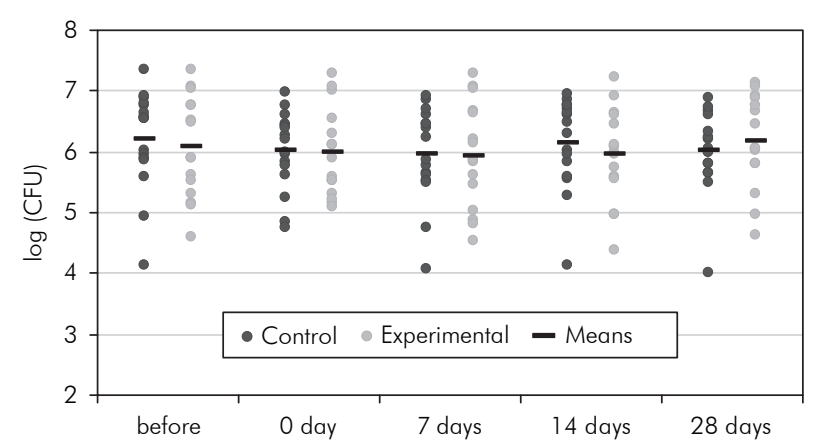

Graph 1 - S. mutans log(CFU) in saliva per group before treatment, at $0,7,14$ and 28 days, and mean values. 
Table 2 - Means, standard deviations, minimum and maximum values of $S$. mutans $\log (C F U)$ in plaque according to group and treatment time point.

\begin{tabular}{c|l|c|c|c|c}
\hline Time & \multicolumn{1}{|c|}{ Group } & Mean & SD & minimum & maximum \\
\hline \multirow{2}{*}{7 days } & Control & 3.697 & 0.565 & 4.342 & 2.439 \\
\cline { 2 - 6 } & Experimental & 3.116 & 0.687 & 4.152 & 2.079 \\
\hline \multirow{2}{*}{14 days } & Control & 3.729 & 0.355 & 4.197 & 3.041 \\
\cline { 2 - 6 } & Experimental & 3.241 & 0.706 & 4.405 & 1.903 \\
\hline \multirow{2}{*}{28 days } & Control & 3.523 & 0.298 & 4.092 & 2.906 \\
\cline { 2 - 6 } & Experimental & 3.322 & 0.537 & 4.454 & 2.255 \\
\hline
\end{tabular}

(1)Hotelling's T-squared test: $F=0.642 ; d f=2$ and $28 ; p=0.543$.

The results of the Hotelling's T-squared test used to compare the effect of elastomeric material on the formation of $\mathrm{CFU}$ in plaque $(\mathrm{F}=0.642 ; \mathrm{df}=2$ and 28; $\mathrm{p}=0.543$ ) show that there was no statistically significant difference between $\log (\mathrm{CFU})$ means at each time point in both groups (Table 2). Therefore, there is no statistical evidence that the type of material used may significantly affect the number of CFU in plaque during the treatment.

Graph 2 shows the values of $\log (\mathrm{CFU})$ in plaque according to group at the three collection times. Despite the apparent difference in variability of $\log (\mathrm{CFU})$ between groups, the Box's test of equality of covariance matrices shows that there is no evidence to reject the hypothesis of equality $(\mathrm{F}=2.01$; $\mathrm{df}=6$ and $6061 ; \mathrm{p}=0.062$ ).

\section{Discussion}

The purpose of this study was to evaluate the effect of fluoride-releasing elastomers on the control of Streptococcus mutans levels in the oral cavity according to the number of colony forming units (CFU) in saliva and plaque for 28 days. Results showed that the fluoride released by the elastomeric ligature ties did not effectively control the progression of colony formation of these microorganisms around the orthodontic appliance. No significant changes in the number of CFUs were found in plaque, which suggests that fluoride did not have antibacterial action. In contrast, studies that evaluated the effect of fluoride-releasing elastomers on the incidence of enamel decalcification in areas surrounding ortho-

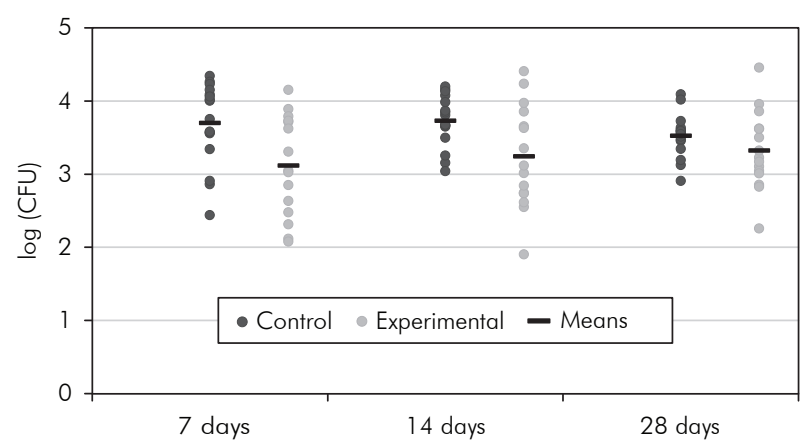

Graph 2 - S. mutans log (CFU) in plaque per group at 7, 14 and 28 days, and mean values.

dontic brackets ${ }^{2,12,21,23,25}$ demonstrated their antibacterial efficacy and showed that these elastomers significantly reduced the degree of enamel decalcification during orthodontic treatment.

Wiltshire ${ }^{25}$ (1996) found a great initial release on the $1^{\text {st }}$ and $2^{\text {nd }}$ days, followed by a logarithmic decrease. At the end of the second week, $88 \%$ of the total fluoride had already been released, but adequate amounts were still released for the rest of the study period, which contributed to the prevention of demineralization and enhanced remineralization through calcium fluoride and fluorapatite formation. These findings, however, were based on results of in vitro studies without clinical control or evidence. According to that author, fluoride-releasing elastomers should be replaced monthly to yield clinical benefits.

Wilson, Love ${ }^{24}$ (1995) investigated the action of fluoride on the levels of microhardness of cervical enamel in in vivo models. Results showed that enamel resistance had a significant increase at a 20 micrometer depth in the region where fluoride-releasing elastomers were used.

Banks et al. ${ }^{2}$ (2000) showed that, after orthodontic treatment, $26 \%$ of the teeth in $73 \%$ of their patients that used conventional ligature ties had enamel decalcification. In the group of patients that used fluoride-releasing elastomeric ligature ties, only $16 \%$ of the teeth of $63 \%$ of the patients were affected, which showed, therefore, that there was a significant difference between the two groups. They also suggested that the use of this material might be 
beneficial if ties were changed at each consultation.

Mattick et al. ${ }^{14}$ (2001) showed that the use of fluoride-releasing elastomers significantly reduced demineralization during orthodontic treatment, and that they may contribute to minimizing iatrogenic decalcification, but may not eliminate its incidence.

Wilson, Gregory ${ }^{23}$ (1995) found a significant reduction of $S$. mutans in saliva in the first week in their experimental group, which demonstrated the antibacterial action of this orthodontic accessory. According to those authors, in the second week after the placement of the elastomers, the levels were back to normal, which suggested little or no release of fluoride ions or that $S$. mutans had become resistant to the antibacterial effects of stannous fluoride.

Differently from the results of Wilson, Gregory ${ }^{23}$ (1995), the results of the present study showed that this material did not cause any significant change in the amount of Streptococcus mutans in saliva or plaque, although the levels of Streptococcus mutans in plaque were lower with fluoride-releasing elastomeric ligature ties (experimental group) than with conventional ligature ties (control group). This difference, however, was not significant. Benson et al. ${ }^{3}$ (2004) also found that fluoridated elastomers were not effective in the reduction of streptococcal growth after a clinically relevant time.

Storie, Regennitter ${ }^{21}$ (1994) suggested that the short antibacterial action of fluoridated materials may be explained by the fact that stannous fluoride released by this material does not stay long in the oral cavity and reported that about $3 \mathrm{mg} / \mathrm{l}$ of fluoride ions were released by Fluor-I-Chain during the three

\section{References}

1. Balenseifen JW, Madonia JV. Study of dental plaque in orthodontic patients. J Dent Res. 1970;49(2):320-4.

2. Banks PA, Chadwick SM, Asher-McDade C, Wright JL. Fluoride-releasing elastomerics - a prospective controlled clinical trial. Eur J Orthod. 2000;22(4):401-7.

3. Benson PE, Douglas CW, Martin MV. Fluoridated elastomers: effect on the microbiology of plaque. Am J Orthod Dentofacial Orthop. 2004;126(3):325-30.

4. Chang HS, Walsh LJ, Freer TJ. The effect of orthodontic treatment on salivary flow, $\mathrm{pH}$, buffer capacity and levels weeks of their study. However, ligature chains had released $1.69 \mathrm{mg} / \mathrm{l}$ or $57 \%$ of the total amount of fluoride after 24 hours. In one week, the mean value was $2.65 \mathrm{mg} / \mathrm{l}$, that is, $90 \%$ of the total amount of fluoride ions available. In situ studies conducted by Doherty et al. ${ }^{6}$ (2002) in dental enamel with superficial carious lesions showed mineral loss, changes in depth and width of preexisting carious lesions in the control (conventional material) and experimental (fluoride-releasing material) groups. Their results showed that there were no significant anticariogenic benefits in the use of fluoride-releasing elastomers in orthodontic patients because mineral loss and similar increases in depth and width of lesions were observed in all samples of dental enamel analyzed.

The clinical efficacy of fluoride-releasing elastomers in reducing the number of $S$. mutans and preventing demineralization should be evaluated in clinical studies using shorter time intervals and fluoride applications to enhance the action of these materials.

\section{Conclusion}

The results of this study suggest that fluoride-releasing elastomeric ligature ties should not be used to reduce the incidence of enamel decalcification in orthodontic patients whose oral hygiene is less than perfect because there was no significant reduction in S. mutans in saliva or plaque in the areas surrounding the fluoride-releasing elastomeric ligature ties. Other means of prevention against enamel decalcification should, therefore, be indicated to these patients.

of mutans streptococci and lactobacilli. Aust Orthod J. 1999;15(4):229-34.

5. Diamanti-Kipioti A, Gusberti FA, Lang NP. Clinical and microbiological effects of fixed orthodontic appliances. J Clin Periodontol. 1987;14(6):326-33.

6. Doherty UB, Benson PE, Highan SM. Fluoride-releasing elastomeric ligatures assessed with the in situ caries model. Eur Orthod Soc. 2002;24(4):371-8.

7. Ferretti GA, Tanzer JM, Tinanoff N. The effect of fluoride and stannous ions on Streptococcus mutans. Caries Res. 1982;16(4):298-307. 
8. Fournier A, Payant L, Bouclin R. Adherence of Streptococcus mutans to orthodontic brackets. Am J Orthod Dentofacial Orthop. 1998;114(4):414-7.

9. Geiger AM, Gorelick L, Gwinnett AJ, Benson BJ. Reducing white spot lesions in orthodontic population with fluoride rinsing. Am J Orthod Dentofacial Orthop. 1992;101(5):403-7.

10. Gorelick L, Geiger AM, Gwinnett AJ. Incidence of white spot formation after bonding and banding. Am J Orthod Dentofacial Orthop. 1982;81(2):93-8.

11. Ikeda T, Sandham HJ, Bradley EL. Changes in Streptococcus mutans and lactobacilli in plaque in relation to the initiation of dental caries in Negro children. Arch Oral Biol. 1973;18(4):555-66.

12. Joseph VP, Grobler SR, Rossouw PE. Fluoride release from orthodontic elastic chain. J Clin Orthod. 1993;27(2):101-5.

13. Lundström F, Krasse B. Streptococcus mutans and lactobacilli frequency in orthodontic patients; the effect of chlorhexidine treatments. Eur J Orthod. 1987;9(2):109-16.

14. Mattick CR, Mitchell L, Chadwick SM, Wright J. Fluoridereleasing elastomeric modules reduce decalcification: a randomized controlled trial. J Orthod. 2001;28(3):217-9.

15. Mitchell L. Decalcification during orthodontic treatment with fixed appliances - an overview. Br J Orthod. 1992;19(3):199205.

16. Ogaard B. Prevalence of white spot lesions in 19-year-olds: a study on untreated and orthodontically treated persons 5 years after treatment. Am J Orthod Dentofacial Orthop. $1989 ; 96(5): 423-7$.
17. Platcheck P, Bolognese AM. Retenção do fluoreto no esmalte humano após utilização de elastômeros sintéticos impregnados com $\mathrm{SnF}_{2}$ - Parte I. Rev SOB. 1998;3(6):219-24.

18. Platcheck P, Bolognese AM. Retenção do fluoreto no esmalte humano após utilização de elastômeros sintéticos impregnados com $\mathrm{SnF}_{2}$ - Parte II. Rev SOB. 1999;3(7):264-70.

19. Rosenbloom RG, Tinanoff N. Salivary Streptococcus mutans levels in patients before, during, and after orthodontic treatment. Am J Orthod Dentofacial Orthop. 1991;100(1):35-7.

20. Scheie AA, Arneberg P, Krogstad O. Effect of orthodontic treatment on prevalence of Streptococcus mutans in plaque and saliva. Scand J Dent Res. 1984;92(3):211-7.

21. Storie DJ, Regennitter F. Characteristics of fluoride-releasing elastomeric chain. Angle Orthod. 1994;64(3):199-210.

22. Todd MA, Staley RN, Kanellis MJ, Donly KJ, Wefel JS. Effect of a fluoride varnish on demineralization adjacent to orthodontic brackets. Am J Orthod Dentofacial Orthop. 1999;116(2):159-67.

23. Wilson TG, Gregory R. Clinical effectiveness of fluoride-releasing elastomers. I: Salivary Streptococcus mutans numbers. Am J Orthod Dentofacial Orthop. 1995;107(3):293-7.

24. Wilson TG, Love B. Clinical effectiveness of fluoride-releasing elastomers. II: Enamel microhardness levels. Am J Orthod Dentofacial Orthop. 1995;107(4):379-81.

25. Wiltshire WA. Determination of fluoride from fluoride-releasing elastomeric ligature ties. Am J Orthod Dentofacial Orthop. 1996;110(4):383-7.

26. Zachrisson BU. Fluoride application procedures in orthodontic practice, current concepts. Angle Orthod. 1975;45(1):72-81. 